\title{
Antiemetic efficacy and safety of granisetron or palonosetron alone and in combination with a corticosteroid for ABVD therapy-induced nausea and vomiting
}

Mayako Uchida ${ }^{1,2^{*}}$, Tsutomu Nakamura ${ }^{2}$, Kojiro Hata ${ }^{1}$, Hiroyuki Watanabe ${ }^{1}$, Yasuo Mori ${ }^{3}$, Koji Kato $^{3}$, Kenjiro Kamezaki ${ }^{3}$, Katsuto Takenaka ${ }^{3}$, Motoaki Shiratsuchi ${ }^{4}$, Keiko Hosohata ${ }^{2}$, Toshihiro Miyamoto ${ }^{3}$ and Koichi Akashi ${ }^{3}$

\begin{abstract}
Background: Antiemetic effects and safety of granisetron or palonosetron alone and in combination with a corticosteroid against chemotherapy-induced nausea and vomiting (CINV) were retrospectively evaluated in patients with Hodgkin lymphoma receiving adriamycin, bleomycin, vinblastine, and dacarbazine (ABVD) therapy.

Methods: A total of 39 patients were eligible for this study. Before ABVD therapy, granisetron or palonosetron was intravenously administered with or without a corticosteroid (dexamethasone or hydrocortisone) and aprepitant. The proportions of patients with complete control (CC) during the overall (0-120 h after the start of ABVD therapy), acute ( $0-24 \mathrm{~h})$ and delayed (24-120 h) phases were evaluated. CC was defined as no vomiting and no use of antiemetic rescue medication with only grade $0-1$ nausea.
\end{abstract}

Results: Granisetron and palonosetron were administered in 21 and 18 patients, respectively. The CC rate during the acute, delayed and overall phases was not statistically different between the two groups. The CINV was completely controlled during overall phase in $58.3 \%$ of patients receiving granisetron or palonosetron in combination with a corticosteroid, whereas in $11.1 \%$ of those without co-treatment of a corticosteroid $(P<0.05)$. There were significantly higher frequencies of anorexia, leucopenia and neutropenia in the palonosetron group. There is a statistically significant difference in the frequency of febrile neutropenia between presence and absence of a corticosteroid ( $p=0.024)$.

Conclusion: These findings suggested that a combination use of a corticosteroid with a $5-\mathrm{HT}_{3}$ receptor antagonist was preferable for CINV control in patients with Hodgkin lymphoma receiving ABVD therapy, although the careful management of febrile neutropenia is required.

Trial registration: The study approval numbers in the institution; 24-12 and 24-359. Registered April 17, 2012 and June 21, 2012.

Keywords: Granisetron, Palonosetron, Chemotherapy-induced nausea and vomiting, Complete response, Delayed phase, Corticosteroid

\footnotetext{
* Correspondence: mayaco@gly.oups.ac.jp

'Department of Pharmacy, Kyushu University Hospital, 3-1-1, Maidashi,

Higashi-ku, Fukuoka 812-8582, Japan

${ }^{2}$ Education and Research Center for Clinical Pharmacy, Osaka University of

Pharmaceutical Sciences, 4-20-1 Nasahara, Takatsuki, Osaka 569-1094, Japan

Full list of author information is available at the end of the article
} 


\section{Background}

Hodgkin lymphoma is a type of lymphoma, which is a blood cancer that starts in the lymphatic system. Adriamycin, bleomycin, vinblastine, and dacarbazine (ABVD) therapy is a representative standard therapy for Hodgkin lymphoma. Chemotherapy can commonly induces nausea and vomiting, which are severe problematic adverse drug events (ADEs) for patients with cancer [1]. Therefore, to control chemotherapy-induced nausea and vomiting (CINV) adequately is very important for improving quality of life of cancer patients.

According to some antiemetic guidelines, ABVD therapy is classified as highly emetogenic chemotherapy (HEC) [2-4]. The use of a serotonin (5-hydroxytryptamine; $5-\mathrm{HT})$ type $3\left(5-\mathrm{HT}_{3}\right)$ receptor antagonist, such as granisetron and palonosetron, in combination with dexamethasone and aprepitant is recommended for antiemetic management of CINV with HECs. CINV is often classified as either acute or delayed, which are defined as occurring within $24 \mathrm{~h}$ and more than $24 \mathrm{~h}$ after the start of the chemotherapy, respectively. The first-generation $5-\mathrm{HT}_{3}$ receptor antagonist, such as granisetron, showed a highly prophylactic effect against acute CINV, but demonstrated less effect against delayed CINV [5]. On the contrary, it has been reported that the secondgeneration palonosetron had the antiemetic effects superior to those of the first-generation $5-\mathrm{HT}_{3}$ receptor antagonists ondansetron [6, 7] and dolasetron [8] during the overall, acute, and delayed phases. In our present study, the ability of palonosetron compared to granisetron to appropriately suppressed delayed CINV in patients receiving rituximab, cyclophosphamide, doxorubicin, vincristine, and prednisolone in combination therapy therapy [9], although it is unclear which is more effective against CINV associated with ABVD therapy, granisetron- or palonosetron-based antiemetic treatment.

Meanwhile, in patients with Hodgkin lymphoma, the lymphocytes grow abnormally and spread beyond the lymphatic system, although which helps the immune system get rid of waste and fight infections under normal conditions. It is considered that most patients receiving ABVD therapy are in a state of immunosuppression $[10,11]$, and so the administration of corticosteroids including dexamethasone for the prevention of CINV may lead to excess immunosuppression. However, it remains unclear whether no use of corticosteroids influence the antiemetic efficacy and the frequency of ADEs in patients with Hodgkin lymphoma receiving ABVD therapy.

In the present study, the effect and safety of the antiemetic regimens with or without a corticosteroids against CINV in patients with Hodgkin lymphoma receiving ABVD therapy were assessed, and those were also compared between granisetron and palonosetron which are first- and second-generation $5-\mathrm{HT}_{3}$ receptor antagonists, respectively.

\section{Methods \\ Patients}

In the present study, eligible participants were patients aged between 20 and 65 years who received ABVD chemotherapy as the treatment for Hodgkin lymphomas in the Department of Hematology, Kyushu University Hospital (April 2007 to December 2015). Patients were excluded if they had hyponatremia, hypercalcemia, adrenal metastasis, or an Eastern Cooperative Oncology Group performance status (ECOG-PS) score of more than 2; had nausea and/or vomiting in the last $24 \mathrm{~h}$ prior to treatment initiation; or were taking laxative agents and antiemetic drugs including olanzapine and lorazepam.

\section{Dosage and administration}

The ABVD therapy regimen is shown in Table 1. Adriamycin $\left(25 \mathrm{mg} / \mathrm{m}^{2}\right)$ was administered on days 1 and 15. Bleomycin $\left(10 \mathrm{mg} / \mathrm{m}^{2}\right.$ up to $15 \mathrm{mg} /$ body $)$, vinblastine $\left(6 \mathrm{mg} / \mathrm{m}^{2}\right.$ up to $10 \mathrm{mg} /$ body), and dacarbazine $(375 \mathrm{mg} /$ $\mathrm{m}^{2}$ ) were administered on days 1 and 15 . Twenty-eight days were defined as one course. Granisetron (3 mg/ body) or palonosetron ( $0.75 \mathrm{mg} /$ body) were intravenously administered 30 min before the initiation of ABVD therapy. Dexamethasone was administered at a dose of $3.3,6.6$ or $8.25 \mathrm{mg}$ in 3 patients on days 1 and 15, and hydrocortisone $(100 \mathrm{mg})$ was administered on days 1 and 15 in 9 patients. The administration of the corticosteroids were carried out intravenously $30 \mathrm{~min}$ prior to chemotherapy treatment once daily on days 1 and 15. Aprepitant was orally administered at a dose of $125 \mathrm{mg}$ once daily one hour before start of chemotherapy on days 1 and at a dose of $80 \mathrm{mg}$ once daily on days 2 and 3 in the morning for each cycle.

Table 1 ABVD therapy regimen

\begin{tabular}{llll}
\hline Drugs $^{\text {a,b }}$ & $\begin{array}{l}\text { Daily } \\
\text { dosage }\end{array}$ & $\begin{array}{l}\text { Route of } \\
\text { administration }\end{array}$ & $\begin{array}{l}\text { Timing of } \\
\text { administration }\end{array}$ \\
\hline Adriamycin & $25 \mathrm{mg} / \mathrm{m}^{2}$ & $\begin{array}{l}\text { 15-min i.v. } \\
\text { infusion }\end{array}$ & once daily on days 1 and 15 \\
Bleomycin $^{c}$ & $10 \mathrm{mg} / \mathrm{m}^{2}$ & $\begin{array}{l}\text { 15-min i.v. } \\
\text { infusion }\end{array}$ & once daily on days 1 and 15 \\
Vinblastine $^{\text {d }}$ & $6 \mathrm{mg} / \mathrm{m}^{2}$ & $\begin{array}{l}\text { 15-min i.v. } \\
\text { infusion }\end{array}$ & once daily on days 1 and 15 \\
Dacarbazine & $375 \mathrm{mg} / \mathrm{m}^{2}$ & $\begin{array}{l}\text { 2-h i.v. } \\
\text { infusion }\end{array}$ & once daily on days 1 and 15
\end{tabular}

i.v. intravenously

${ }^{a}$ Granisetron ( $3 \mathrm{mg} / \mathrm{body}$ ) was intravenously administered on days 1 and 15

${ }^{b}$ Palonosetron ( $0.75 \mathrm{mg} /$ body) was intravenously administered on days 1 and 15

${ }^{c}$ Maximum daily dose was $15 \mathrm{mg}$

${ }^{\mathrm{d}}$ Maximum daily dose was $10 \mathrm{mg}$ 
Metoclopramide, prochlorperazine, haloperidol, and/or hydroxyzine were used as rescue medications.

\section{Data collection and assessment}

All data were collected from the electronic medical record system. The data after the second course were excluded in order to remove confounding factors such as predictive nausea and vomiting. The occurrence of nausea, vomiting, or use of rescue medication during the overall (0 to $120 \mathrm{~h}$ after the start of ABVD therapy), acute $(0$ to $24 \mathrm{~h}$ ), and delayed ( 24 to $120 \mathrm{~h}$ ) phases were assessed. ADEs including nausea and vomiting, were monitored during the overall study period and described in the electronic medical record system twice a day (morning and evening) by doctors, nurses, and pharmacists, according to the Common Terminology Criteria for Adverse Events (CTCAE) v.4.0.

This study was conducted in accordance with the Declaration of Helsinki and its amendments.

The endpoint of this study was the proportion of patients with complete control (CC) during the overall, acute, and delayed phases. CC was defined as complete response (CR) and no more than mild nausea (grade 0 or 1 ).

\section{Statistical analysis}

Statistical analysis was performed using JMP13 software (SAS Institute Inc. Cary, NC, USA). Fisher's exact test was used to examine differences in frequencies of categorical data between the granisetron and palonosetron groups. The statistical significance of the difference between the median values of age was calculated with the Mann-Whitney U-test. In the univariate analysis, sex, age, ECOG-PS, and use of granisetron, palonosetron, a corticosteroid and aprepitant were chosen as variables. The factors with $p$ values $<0.10$ in univariate analyses were included in a stepwise multivariate logistic regression analysis with backward selection. Two-tailed $\mathrm{p}$ values of less than 0.05 were considered to indicate a statistically significant difference.

\section{Results}

\section{Patient baseline clinical characteristics}

A total of 44 patients participated, but 5 patients were excluded from the study because they failed to meet inclusion criteria or had missing data. The patients' baseline clinical characteristics are shown in Table 2. There was no significant difference in the variables between the granisetron and palonosetron groups.

\section{Antiemetic effects}

In $38.5 \%$ of 39 patients receiving ABVD therapy, CINV was completely controlled by treatment with granisetron or palonosetron during the overall study period,
Table 2 Patient characteristics

\begin{tabular}{|c|c|c|c|}
\hline Variable & $\begin{array}{l}\text { Granisetron } \\
(n=21)\end{array}$ & $\begin{array}{l}\text { Palonosetron } \\
(n=18)\end{array}$ & $p$ value \\
\hline Number of patients & 21 & 18 & \\
\hline \multicolumn{4}{|l|}{ Sex } \\
\hline Male & 11 & 5 & \multirow[t]{2}{*}{0.192} \\
\hline Female & 10 & 13 & \\
\hline \multicolumn{4}{|l|}{ Age } \\
\hline Median, year (range) & $30(20-55)$ & $31(25-58)$ & 0.863 \\
\hline \multicolumn{4}{|l|}{ Age (years) } \\
\hline$\geq 35$ & 8 & 8 & \multirow[t]{2}{*}{0.752} \\
\hline$<35$ & 13 & 10 & \\
\hline \multicolumn{4}{|l|}{ ECOG-PS ${ }^{a}$ score } \\
\hline 0 & 20 & 16 & \multirow[t]{2}{*}{0.586} \\
\hline 1 & 1 & 2 & \\
\hline \multicolumn{4}{|l|}{ Combined antiemetics } \\
\hline None & 6 & 5 & \multirow[t]{4}{*}{0.633} \\
\hline Corticosteroid $^{b}$ & 0 & 2 & \\
\hline Aprepitant & 9 & 7 & \\
\hline Corticosteroid + Aprepitant & 6 & 4 & \\
\hline
\end{tabular}

${ }^{a}$ ECOG-PS, Eastern Cooperative Oncology Group performance status

${ }^{\mathrm{b}}$ Corticosteroids included dexamethasone or hydrocortisone

although the nausea and vomiting in 24 patients were not. The $\mathrm{CC}$ rates were not significantly different between the granisetron and palonosetron groups during the overall, acute, and delayed phases (Fig. 1). The univariate analyses were performed to detect factors influencing CINV control. When a corticosteroid was combined as antiemetic agents, the $\mathrm{CC}$ rates were significantly higher than those in the group without a corticosteroid throughout the study period (Fig. 2). Thirtyfive years of age and above was also a significant factor

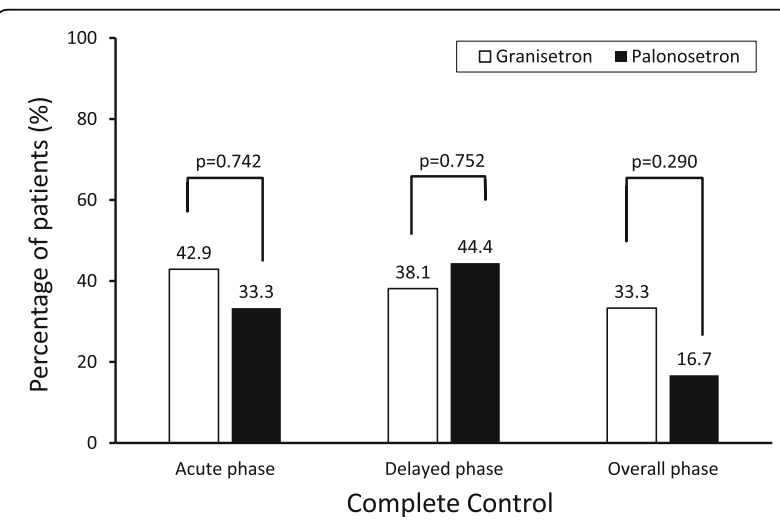

Fig. 1 Complete control by phase. The bar shows the percentage of patients achieving complete control (CC) during the acute (0-24 h after initiation of chemotherapy), delayed (24-120 h) and overall phases. CC was defined as no vomiting and no use of antiemetic rescue medication with only grade 0-1 nausea. White and black bars represent the granisetron- and palonosetron-based antiemetic regimens, respectively 


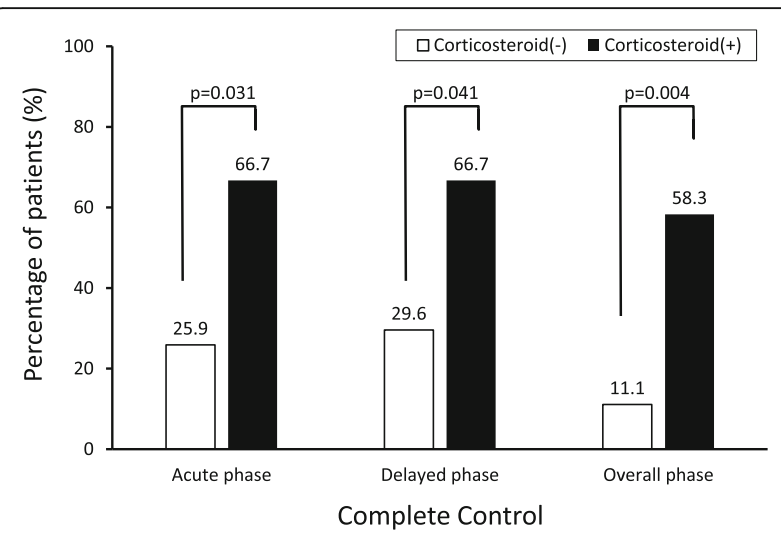

Fig. 2 Effect of co-treatment with a corticosteroid on the rate of complete control by phase. The bar shows the percentage of patients achieving complete control (CC) during the acute (0-24 h after initiation of chemotherapy), delayed (24-120 h) and overall phases. CC was defined as no vomiting and no use of antiemetic rescue medication with only grade 0-1 nausea. White and black bars represent the absence and presence of a corticosteroid, respectively. Corticosteroids included dexamethasone or hydrocortisone

that improved the $\mathrm{CC}$ rate during the delayed phase, and multivariate logistic regression analysis showed that corticosteroid use (odds ratio, 5.4; 95\% confidence interval, 1.0 to 29.1) and 35 years of age and above (odds ratio, $8.7 ; 95 \%$ confidence interval, 1.8 to 42.2 ) were independent factors associated with complete control of CINV. Sex, ECOG-PS, generation of $5-\mathrm{HT}_{3}$ receptor antagonist, and aprepitant use were not identified as a significant influencing factor during any of the phases.

\section{Adverse drug events (ADEs)}

The numbers of patients experiencing side effects (SEs) in the granisetron and palonosetron groups are shown in Table 3. The most frequent SEs was anorexia and it

Table 3 Number of patients experiencing SEs in palonosetron and granisetron groups

\begin{tabular}{llll}
\hline SEs $^{\mathrm{a}}$ & $\begin{array}{l}\text { Granisetron } \\
(n=21)\end{array}$ & $\begin{array}{l}\text { Palonosetron } \\
(n=18)\end{array}$ & $p$ value $^{\mathrm{b}}$ \\
\hline Anorexia & $15(71.4 \%)$ & $18(100 \%)$ & 0.022 \\
Malaise & $8(38.1 \%)$ & $13(72.2 \%)$ & 0.054 \\
Leucopenia & $4(19.1 \%)$ & $12(66.7 \%)$ & 0.004 \\
Neutropenia & $3(14.3 \%)$ & $12(66.7 \%)$ & 0.001 \\
Fever & $3(14.3 \%)$ & $6(33.3 \%)$ & 0.255 \\
$\quad 3(14.3 \%)$ & $3(16.7 \%)$ & 1.000 \\
Oral mucositis & $3(14.3 \%)$ & $0(0 \%)$ & 0.235 \\
Cobrile Neutropenia & $2(9.5 \%)$ & $5(27.8 \%)$ & 0.216 \\
Headache & $2(9.5 \%)$ & $2(11.1 \%)$ & 1.000 \\
Neuropathy & $2(9.5 \%)$ & $0(0 \%)$ & 0.490 \\
Diarrhea & $2(9.5 \%)$ & $0(0 \%)$ & 0.490 \\
\hline
\end{tabular}

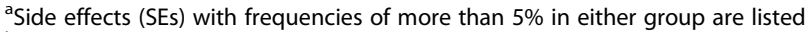
${ }^{\mathrm{b}} \mathrm{A}$ significant difference is in italics occurred in more than $70 \%$ patients in both the granisetron and palonosetron groups. Over half of the patients in the palonosetron group experienced anorexia, malaise, leucopenia, and neutropenia, and the frequencies of anorexia, leucopenia and neutropenia were significantly higher than those of the SEs in the granisetron group. There was also statistical significant difference in the frequency of malaise between the two groups. Fever and oral mucositis and were also observed at the frequencies of more than $10 \%$ in both the granisetron and palonosetron groups, although there was not statistically significant difference. Febrile neutropenia occurred when the patients were treated with the antiemetics in combination with granisetron (Table 3). All these patients was also treated with a corticosteroid. There was a statistically significant difference in the frequency of febrile neutropenia between the antiemetic treatments with or without a corticosteroid $(p=0.024)$. No statistically significant difference was detected in the frequencies of SEs other than febrile neutropenia between the two groups. The addition of aprepitant to granisetron- or palonosetron-based antiemetic therapy did not significantly produce any increase in the frequency of SEs.

\section{Discussion}

The ABVD regimen includes dacarbazine, which is a classified as a HEC agent [2-4]. The ABVD therapy caused severe nausea and vomiting in about $50 \%$ of patients before the use of antiemetic agents is recommended [12], and thereby patients may refuse to complete its planned cycles [13]. To date, it has been reported that antiemetic regimens including the first-generation $5-\mathrm{HT}_{3}$ receptor antagonists, ondansetron and granisetron, were more effective for CINV control in patients with Hodgkin and non-Hodgkin lymphomas receiving moderately emetogenic chemotherapy (MEC), compared to metoclopramide-based antiemetic regimens [14, 15]. In patients with HEC, to prevent CINV induced by ABVD therapy, triple antiemetic therapy (a $5-\mathrm{HT}_{3}$ receptor antagonist, dexamethasone, aprepitant) is recommended, although the data regarding the antiemetic effects of these medications are not entirely sufficient for patients with hematological malignancies. In the present study, dexamethasone was used as a corticosteroid in three patients. One patient treated with dexamethasone in combination with palonosetron and aprepitant achieved $\mathrm{CC}$, whereas the other two treated with dexamethasone and granisetron did not. The superiority of palonosetron to the first generation $5-\mathrm{HT}_{3}$ receptor antagonists has been reported from the viewpoint of antiemetic prophylaxis for acute, delayed and overall phases in populations of patients of whom most had solid cancer $[6,7,16-18]$. However, it remains unclear which of firstor second-generation $5-\mathrm{HT}_{3}$ receptor antagonists are 
more effective in a triple antiemetic therapy in Hodgkin lymphoma patients receiving ABVD therapy, and future large scale studies are required to address this issue.

Dexamethasone is recommended for the prevention of delayed emesis following HEC and MEC [19]. Though it seems that clinical interest has trended toward the reduction of steroid use [20-23]. In the present study, the antiemetic treatment of dexamethasone or hydrocortisone in combination of a $5-\mathrm{HT}_{3}$ receptor antagonist improved the $\mathrm{CC}$ rate during acute, delayed and overall phases, compared to the therapy without corticosteroids (Fig. 2). This suggested that an addition of a corticosteroid was more effective in preventing CINV in the patients with Hodgkin Lymphoma receiving ABVD therapy. Meanwhile, of concern is the possibility that the risk of infection is elevated by use of steroids. During the observation period, there was a statistically significant difference in frequencies of febrile neutropenia between presence and absence of a combination of a corticosteroid (25\% and $0 \%$, respectively, $p=0.024)$. All patients with febrile neutropenia were treated with granisetron as a $5-\mathrm{HT}_{3}$ receptor antagonist, but its frequency was not statistically significant different from that in those treated with palonosetron (Table 3). Meanwhile, fever and oral mucositis were also observed in both the granisetron and palonosetron groups (Table 3). The ADEs observed during the study period were possibly attributed to the ABVD therapy as well as the $5-\mathrm{HT}_{3}$ receptor antagonist-based antiemetic therapy, although the extent of which remains unclear. Further investigations with relatively large number of subjects should be undertaken to confirm these preliminary results. Collectively, palonosetron or granisetron in combination with a corticosteroid could control CINV effectively during the cycles of ABVD treatment, although the careful management of febrile neutropenia is required.

Aprepitant has the potential to inhibit cytochrome P450 (CYP) 3A4 [24]. It may influence the pharmacokinetics of the drugs including vinblastine and corticosteroids, which are metabolized by CYP 3A4, and thereby increase the risk of ADEs during ABVD therapy and CINV management $[25,26]$. In the present study, univariate analysis found no significant association of aprepitant use, unlike to corticosteroid use, with the $\mathrm{CC}$ rate and the frequencies of the ADEs during the study period. Therefore, we considered that the druginteraction did not considerably influence CINV control during ABVD therapy.

To date, it has been reported that younger age, female sex, and/or no alcohol intake were risk factors reducing the degree of response to antiemetic therapy including ondansetron (a $5-\mathrm{HT}_{3}$ receptor antagonist), dexamethasone, and aprepitant during cancer chemotherapy [27, 28]. In the present study, the multivariate logistic regression analysis showed that age less than 35 years, but not female sex, was an independent significant factor complicating CINV management during the delayed phase. The cause of the discrepancy between the results was unclear, although it might be attributed to the difference in chemotherapy and antiemetic regimens. Our present pilot study was limited by small sample size and lack of racial and ethnic diversity, and further studies are required to address these issues.

Regarding treatment-related SEs, the frequency of anorexia, leucopenia, neutropenia and stomatitis in the palonosetron group was significantly higher than that in the granisetron group in the present study (Table 3). This was almost consistent with the result of our previous report in patients with malignant lymphoma receiving first-line rituximab, cyclophosphamide, doxorubicin, vincristine, and prednisone [9]. The interaction of a $5-\mathrm{HT}_{3}$ receptor antagonist with its target receptor families can affect the peripheral and central nervous system and the immune responses as well [29-31], possibly associated with the above-mentioned SEs. Besides, palonosetron has a higher binding affinity for the $5-\mathrm{HT}_{3}$ receptor and a longer half-life, compared to those of granisetron [32]. Therefore the difference in the frequencies of the SEs between the granisetron and palonosetron groups may reflect the difference in the pharmacological and pharmacokinetic properties of these two antiemetics, although further studies are warranted. As mentioned above, there is no statistically difference in the antiemetic efficacy between granisetronand palonosetron-containing regimens. Considering these findings together, granisetron may be more adequate for CINV control in patients with Hodgkin lymphoma receiving ABVD therapy, although it was needed to examine whether co-treatment of a corticosteroid and/or aprepitant influenced the frequencies of the SEs.

In summary, our present results demonstrated that combination of a corticosteroid with a $5-\mathrm{HT}_{3}$ receptor antagonist significantly improved the CINV control in patients receiving ABVD therapy, whereas the differences between granisetron and palonosetron and between presence and absence of aprepitant did not influence that. These findings suggested that CINV in patients with Hodgkin lymphoma receiving ABVD therapy could be controlled more effectively by a granisetron-based antiemetic regimen in combination with a corticosteroid, although the careful management of febrile neutropenia is required.

\section{Conclusion}

These findings suggested that a combination use of a corticosteroid with a $5-\mathrm{HT}_{3}$ receptor antagonist was preferable for CINV control in patients with Hodgkin lymphoma receiving ABVD therapy. 


\section{Abbreviations}

5- $\mathrm{HT}_{3}$ : 5-Hydroxytryptamine; 5-HT type 3; ABVD: Adriamycin, Bleomycin, Vinblastine, and Dacarbazine; ADEs: Adverse drug events; CC: Complete response; CINV: Chemotherapy-induced nausea and vomiting; CR: Complete response; CTCAE: Common Terminology Criteria for Adverse Events; CYP: Cytochrome P450; ECOG-PS: Eastern Cooperative Oncology Group performance status; HEC: Highly emetogenic chemotherapy; MEC: Moderately emetogenic chemotherapy; SEs: Side effects

\section{Acknowledgements}

We also thank patients, doctors, nurses, pharmacists, and all medical staff at the Kyushu University Hospital, and the staff of the Osaka University of Pharmaceutical Sciences who contributed to this study.

\section{Funding}

The present study was supported in part by a Grant-in-Aid for Research Activity Start-up from the Japan Society for the Promotion of Science (grant no. 16H07349).

\section{Availability of data and materials}

The dataset supporting the conclusions of this article is included within the article.

\section{Authors' contributions}

MU designed this concept originally and performed statistical analyses, writing the manuscript. TN performed statistical analyses, writing the manuscript. $\mathrm{KH}, \mathrm{HW}$ and $\mathrm{YM}$ gathered patient data from electronic medical records. KoK, KeK, KT, MS, KH, TM and KA provided interpretation and discussion of the data. All authors have read and approved the final manuscript.

\section{Ethics approval and consent to participate}

This study was conducted with the approval of Kyushu University Graduate School and Faculty of Medicine (approval Nos. 24-928027 and 24-359 of the institutional review board)

\section{Consent for publication}

Not applicable.

\section{Competing interests}

The authors declare that they have no competing interests.

\section{Publisher's Note}

Springer Nature remains neutral with regard to jurisdictional claims in published maps and institutional affiliations.

\section{Author details}

'Department of Pharmacy, Kyushu University Hospital, 3-1-1, Maidashi, Higashi-ku, Fukuoka 812-8582, Japan. 'Education and Research Center for Clinical Pharmacy, Osaka University of Pharmaceutical Sciences, 4-20-1 Nasahara, Takatsuki, Osaka 569-1094, Japan. ${ }^{3}$ Department of Medicine and Biosystemic Science, Kyushu University Graduate School of Medical Sciences, 3-1-1, Maidashi, Higashi-ku, Fukuoka City 812-8582, Japan. ${ }^{4}$ Department of Medicine and Bioregulatory Science, Kyushu University Graduate School of Medical Sciences, 3-1-1, Maidashi, Higashi-ku, Fukuoka City 812-8582, Japan

Received: 17 August 2017 Accepted: 20 December 2017

Published online: 09 January 2018

\section{References}

1. Hesketh PJ. Chemotherapy-induced nausea and vomiting. N Engl J Med. 2008:358:2482-94

2. NCCN. Clinical Practice Guidelines in Oncology-Antiemesis-Version II. Available from: https://www.nccn.org/professionals/physician_gls/pdf/ antiemesis.pdf. Accessed 25 Dec 2017

3. Hesketh PJ, Bohlke K, Lyman GH, Basch E, Chesney M, Clark-Snow RA, Danso MA, Jordan K, Somerfield MR, Kris MG, American Society of Clinical O. Antiemetics: American Society of Clinical Oncology focused guideline update. J Clin Oncol. 2016;34:381-6.
4. Oncology JSoC. JSCO Clinical Practice Guidelines 2015 for Antiemesis. Available from: http://www.jsco-cpg.jp/item/29/index.html. Accessed 25 Dec 2017.

5. Geling O, Eichler HG. Should 5-hydroxytryptamine-3 receptor antagonists be administered beyond 24 hours after chemotherapy to prevent delayed emesis? Systematic re-evaluation of clinical evidence and drug cost implications. J Clin Oncol. 2005;23:1289-94.

6. Gralla R, Lichinitser M, Van Der Vegt S, Sleeboom H, Mezger J, Peschel C, Tonini G, Labianca R, Macciocchi A, Aapro M. Palonosetron improves prevention of chemotherapy-induced nausea and vomiting following moderately emetogenic chemotherapy: results of a double-blind randomized phase III trial comparing single doses of palonosetron with ondansetron. Ann Oncol. 2003:14:1570-7.

7. Aapro MS, Grunberg SM, Manikhas GM, Olivares G, Suarez T, Tjulandin SA, Bertoli LF, Yunus F, Morrica B, Lordick F, Macciocchi A. A phase III, doubleblind, randomized trial of palonosetron compared with ondansetron in preventing chemotherapy-induced nausea and vomiting following highly emetogenic chemotherapy. Ann Oncol. 2006;17:1441-9.

8. Eisenberg P, Figueroa-Vadillo J, Zamora R, Charu V, Hajdenberg J, Cartmell A, Macciocchi A, Grunberg S, Palonosetron SG. Improved prevention of moderately emetogenic chemotherapy-induced nausea and vomiting with palonosetron, a pharmacologically novel $5-\mathrm{HT}_{3}$ receptor antagonist: results of a phase III, single-dose trial versus dolasetron. Cancer. 2003;98:2473-82.

9. Uchida M, Mori Y, Nakamura T, Kato K, Kamezaki K, Takenaka K, Shiratsuchi M, Kadoyama K, Miyamoto T, Akashi K. Comparison between antiemetic effects of palonosetron and granisetron on chemotherapy-induced nausea and vomiting in Japanese patients treated with R-CHOP. Biol Pharm Bull. 2017:40:1499-505.

10. López-Jiménez J, Martín-Ballesteros E, Sureda A, Uralburu C, Lorenzo I, del Campo R, Fernández C, Calbacho M, García-Belmonte D, Fernández G. Chemotherapy-induced nausea and vomiting in acute leukemia and stem cell transplant patients: results of a multicenter, observational study. Haematologica. 2006;91:84-91.

11. Mattiuzzi GN, Cortes JE, Blamble DA, Bekele BN, Xiao L, Cabanillas M, Borthakur G, O'Brien S, Kantarjian H. Daily palonosetron is superior to ondansetron in the prevention of delayed chemotherapy-induced nausea and vomiting in patients with acute myelogenous leukemia. Cancer. 2010; 116:5659-66.

12. Bonadonna G, Santoro A, Bonfante V, Valagussa P. Cyclic delivery of MOPP and ABVD combinations in stage IV Hodgkin's disease: rationale, background studies, and recent results. Cancer Treat Rep. 1982;66:881-7.

13. Bonadonna G, Santoro A. ABVD chemotherapy in the treatment of Hodgkin's disease. Cancer Treat Rev. 1982:9:21-35.

14. Jørgensen M, Victor MA. Antiemetic efficacy of ondansetron and metoclopramide, both combined with corticosteroid, in malignant lymphoma patients receiving non-cisplatin chemotherapy. Acta Oncol. 1996;35:159-63.

15. Numbenjapon T, Sriswasdi C, Mongkonsritragoon W, Leelasiri A, Prayoonwiwat W. Comparative study of low-dose oral granisetron plus dexamethasone and high-dose metoclopramide plus dexamethasone in prevention of nausea and vomiting induced by CHOP-therapy in young patients with non-Hodgkin's lymphoma. J Med Assoc Thail. 2002;85:1156-63.

16. Saito M, Aogi K, Sekine I, Yoshizawa H, Yanagita Y, Sakai H, Inoue K, Kitagawa C, Ogura T, Mitsuhashi S. Palonosetron plus dexamethasone versus granisetron plus dexamethasone for prevention of nausea and vomiting during chemotherapy: a double-blind, double-dummy, randomised, comparative phase III trial. Lancet Oncol. 2009;10:115-24.

17. Suzuki K, Yamanaka T, Hashimoto H, Shimada Y, Arata K, Matsui R, Goto K, Takiguchi T, Ohyanagi F, Kogure Y, Nogami N, Nakao M, Takeda K, Azuma K, Nagase S, Hayashi T, Fujiwara K, Shimada T, Seki N, Yamamoto N. Randomized, double-blind, phase III trial of palonosetron versus granisetron in the triplet regimen for preventing chemotherapy-induced nausea and vomiting after highly emetogenic chemotherapy: TRIPLE study. Ann Oncol. 2016:27:1601-6.

18. Kubota K, Saito M, Aogi K, Sekine I, Yoshizawa H, Yanagita Y, Sakai H, Inoue K, Kitagawa C, Ogura T. Control of nausea with palonosetron versus granisetron, both combined with dexamethasone, in patients receiving cisplatin- or anthracycline plus cyclophosphamide-based regimens. Support Care Cancer. 2016:24:4025-33.

19. Roila F, Herrstedt J, Aapro M, Gralla RJ, Einhorn LH, Ballatori E, Bria E, Clark-Snow RA, Espersen BT, Feyer P, Grunberg SM, Hesketh PJ, Jordan K, 
Kris MG, Maranzano E, Molassiotis A, Morrow G, Olver I, Rapoport BL, Rittenberg C, Saito M, Tonato M, Warr D, Group EMGW. Guideline update for MASCC and ESMO in the prevention of chemotherapy- and radiotherapy-induced nausea and vomiting: results of the Perugia consensus conference. Ann Oncol. 2010;21(Suppl 5):v232-43.

20. Vardy J, Chiew KS, Galica J, Pond GR, Tannock IF. Side effects associated with the use of dexamethasone for prophylaxis of delayed emesis after moderately emetogenic chemotherapy. Br J Cancer. 2006;94:1011-5.

21. Aapro M, Fabi A, Nole F, Medici M, Steger G, Bachmann C, Roncoroni S, Roila F. Double-blind, randomised, controlled study of the efficacy and tolerability of palonosetron plus dexamethasone for 1 day with or without dexamethasone on days 2 and 3 in the prevention of nausea and vomiting induced by moderately emetogenic chemotherapy. Ann Oncol. 2010;21: 1083-8.

22. Grunberg SM. Antiemetic activity of corticosteroids in patients receiving cancer chemotherapy: dosing, efficacy, and tolerability analysis. Ann Oncol. 2007:18:233-40.

23. Herrstedt J, Roila F, Warr D, Celio L, Navari RM, Hesketh PJ, Chan A, Aapro MS. Updated MASCC/ESMO consensus recommendations: prevention of nausea and vomiting following high emetic risk chemotherapy. Support Care Cancer. 2016;2017(25):277-88.

24. Majumdar AK, McCrea JB, Panebianco DL, Hesney M, Dru J, Constanzer M, Goldberg MR, Murphy G, Gottesdiener KM, Lines CR, Petty KJ, Blum RA. Effects of aprepitant on cytochrome P450 3A4 activity using midazolam as a probe. Clin Pharmacol Ther. 2003;74:150-6.

25. Georgy A, Neceskas J, Goodin S. Antiemetic care for patients with breast cancer: focus on drug interactions and safety concerns. Am J Health Syst Pharm. 2007:64:2227-36.

26. Aapro MS, Walko CM. Aprepitant: drug-drug interactions in perspective. Ann Oncol. 2010;21:2316-23.

27. Hesketh PJ, Aapro M, Street JC, Carides AD. Evaluation of risk factors predictive of nausea and vomiting with current standard-of-care antiemetic treatment: analysis of two phase III trials of aprepitant in patients receiving cisplatin-based chemotherapy. Support Care Cancer. 2010;18:1171-7.

28. Warr DG, Street JC, Carides AD. Evaluation of risk factors predictive of nausea and vomiting with current standard-of-care antiemetic treatment: analysis of phase 3 trial of aprepitant in patients receiving adriamycincyclophosphamide-based chemotherapy. Support Care Cancer. 2011;19: 807-13.

29. Machu TK. Therapeutics of 5-HT3 receptor antagonists: current uses and future directions. Pharmacol Ther. 2011;130:338-47.

30. Herr N, Bode C, Duerschmied D. The effects of serotonin in immune cells. Front Cardiovasc Med. 2017;4:48.

31. Shajib MS, Khan WI. The role of serotonin and its receptors in activation of immune responses and inflammation. Acta Physiol (Oxf). 2015;213:561-74.

32. Maemondo M, Masuda N, Sekine I, Kubota K, Segawa Y, Shibuya M, Imamura F, Katakami N, Hida T, Takeo S, Group PJCS. A phase II study of palonosetron combined with dexamethasone to prevent nausea and vomiting induced by highly emetogenic chemotherapy. Ann Oncol. 2009; 20:1860-6.

\section{Submit your next manuscript to BioMed Central and we will help you at every step:}

- We accept pre-submission inquiries

- Our selector tool helps you to find the most relevant journal

- We provide round the clock customer support

- Convenient online submission

- Thorough peer review

- Inclusion in PubMed and all major indexing services

- Maximum visibility for your research

Submit your manuscript at www.biomedcentral.com/submit

) Biomed Central 